\title{
Libyan English as a Foreign Language School Teachers' (LEFLSTs) Knowledge of Teaching: Action Research as Continuing Professional Development Model for Libyan School Teachers
}

\author{
Dr. Ageila Ali Elabbar \\ Faculty of Education, University of Benghazi
}

\begin{abstract}
Teachers are the source of knowledge, ideas, information and practices to their learners. Libyan English as a foreign language school teachers (LEFLSTs) are doing that in a language that is not their language to students to whom it is not their language, at the same time as they are doing it in a hard cultural context. Teachers are constrained, as teaching is an activity in which the extent to which the teacher can decide what they are going to do is limited because of the way that things are decided. English as a foreign language (EFL) Libyan school teachers may have extra issues and constraints in that they cannot use a lot of the techniques or aids that teachers of other subjects use. This is because they have to work in a language that is not native to the learners. Then, if the teacher is not a native speaker either, it will be another constraint. LEFLSTs may have additional constraints than, for example, a Spanish teacher teaching English to Spanish students. These limitations may come from their cultural settings, such as the impact of Libyan community on learning, impacts of teachers' age and gender, time managements within classrooms, the way learners' use to learn (their learning styles and background knowledge). Besides the last political situation (Gadhafi's era) which has influenced the way that LEFLSTs teach and deal with the foreign languages. In other words, LEFLSTS are strongly controlled by the wall of culture, political interference in education, and their subjects and how to deliver it. Thus, if we pursue to offer support, we need to explore in details the influences affecting their teaching approaches in the language classrooms. It may then be possible to suggest a model or an approach of Continuing Professional Development (CPD) to work within these constraints. This paper is the Third conclusion of my research studies on the Libyan EFL school and university contexts which presented (the two previous researchers) ideas and justifications of implementing Action research as model of CPD for EFL university teachers within the University of Benghazi-Libya. The main research questions are:

- To what extent are knowledge and cultural constrains faced by the LEFLSTs influence they ways, choices and methodologies of teaching?

- To what extent are the possibilities of implementing Action Research as CPD among LEFLSTs?
\end{abstract}

Keywords: Teaching and learning within Libyan context, Teachers' Knowledge and Cultural impacts and suggesting Action Research as CPD.

\section{Introduction}

- Brief about Libya

Libya is an Arabic country located in North Africa between four Arabic countries: Egypt, Tunisia, Algeria and Sudan. Vandewall (2009) showed that the population of Libya is approximately 7.5 million, the majority of whom live mainly in the north of the country. It is the fourth largest country on the African continent. It has a Mediterranean Sea coast line of about 1200 miles. Libya is a large country with an area of about 1.8 million square kilometres, which is seven times the size of the United Kingdom (pp. 5-7).

Agnaia (1996) pointed out that Libya is a bi-lingual country, with the languages spoken being Arabic and Berber. People who speak Berber are a minority, living in the cities of Zuwara and Yefren (western mountains of Libya), who spoke (During Gadhafi regime) their language among themselves and pass it on to their children. Arabic, however, is the only official language in Libya and it also the language used in the educational system, which is not the same as the various dialects spoken in different parts of Libya. Thus, when students enter schools, Arabic-speaking children are exposed to a language which is different from their everyday dialect (pp. $8-10)$.

II. School System In Libya.

Libyan compulsory education is divided into two main structures: the school system and the university system. El-Hawat (2006) reports that elementary school in Libya consists of six years, followed by three years 
of junior high and three years of high school. The secondary school system is divided into two main specialties, Arts and Sciences, comprising six areas of specialization. Libyan school officials view education as "the path to human and technological development and progress" and they are implementing changes to the system to keep pace with the modernization and globalization that is part of modern Libyan society. The creation of two types of secondary school is one example of this, as this new system was started in 2004, and another is the creation of universities based on students' specialisations (pp. 207-208).

In other words, Rajab 2007 mentioned that the compulsory for the pupils to get a certificate allowing them to enter high school. This stage includes 9 years of education, from 6 and 15 years old usually, with two levels: primary and middle. The primary school starts from the age of 6 years until 12 years after which the pupils move to the middle level where they have 3 years of study to finish the compulsory school. This level is ended by a national Examination which is considered by the students as a new and frightening experience (p. 71). The following table shows the current stages of education in Libya by stage, years, ages and period.

\begin{tabular}{|l|l|l|l|}
\hline Stage & Years & Ages & Period \\
\hline Primary & $1-6$ & $6-12$ & 6 years \\
\hline Middle & $7-9$ & $12-15$ & 3 years \\
\hline High schools & $10-13$ & $15-18$ & $\begin{array}{l}\text { 3 years } \\
\text { (used to be 4) }\end{array}$ \\
\hline University & $13-17$ & $18-22$ & $\begin{array}{l}\text { 4 years and some faculties } \\
\text { spend 5 years }\end{array}$ \\
\hline
\end{tabular}

Table (1) Stages of Education in Libya (Adapted from Rajab, 2007 and from Elabbar 2011)

\section{Growth In Education In Libya}

$\begin{array}{lcc}\text { Year } & \text { Number } & \text { Literacy } \\ 1951 & 34000 \text { population } & \text { literacy }<20 \% \\ 1962 & 150000 \text { female } & \text { literacy } ~ 6 \% \\ 1969 & 360000 & \\ 1977 & 980000 \text { overall } & \text { Literacy } 51 \% \text { but females } 31 \% \\ 1986 & 1245000 & \text { Literacy: } 54 \% \text { male, } 46 \% \text { female } \\ 2004 & 1477000 & \text { Literacy: } 92 \% \text { male, } 72 \% \text { female } \\ 2012 & 3856000 & \text { Literacy: } 89 \% \text { male, } 96 \% \text { female } \\ & \\ & \\ \text { (Adapted from Rajab, } 2007 \text { and from Blabber } 2011 \text { ) }\end{array}$

\section{Background About Efl In Libya}

As mentioned in the previous papers that teaching and learning of English as a foreign language in Libya has gone through several stages, Sawani (2009, p. 5-13) showed that during the 1970s and until the mid1980s learning English was a compulsory component of the Libyan schools and universities. However, in 1986, teaching and learning of English were completely cancelled. This was due to the political forces form the former regime (Gadhafi regime) which deeply influenced the educational system at that time. This in turn meant the teachers of English were made "jobless or otherwise had to teach other subjects such as history and geography".

At that time students were unaware of the problem until they finished their secondary school and became university students where their failure to study many subjects in English became evident. Also, Sawani (2009) pointed out that some of those teachers (English teachers who became unable to teach English) practiced a programme called in Arabic Tageer Masar in Libya (which means "change of direction or specialty") to teach other subjects such as history, mathematics or geography in primary and secondary schools. Therefore, some of those teachers preferred to stay where they were and not return to their original specialty ( $\mathrm{p}$. 11).

Moreover, Gadour (2006) explained that the introduction of new textbooks integrated cultural aspects of the English language that required the application of new teaching methodologies. This created an obstacle in the teaching and learning environment because "many teachers have forgotten the English language, but culturally they have to teach it" There were only a few teachers left who were still capable of teaching languages, particularly English (p. 180).

However, IAU (2009) showed that those teachers who struggled during the cancelation of English were often given opportunities to take scholarships to renew their English skills overseas, either in short courses or by taking a degree, such as an MA or $\mathrm{PhD}$ (p. 35). This particular point is one of the causes of the two clearly different generations of teachers (old and new generation teachers (OGT \&NGT)) in Libya.

Also, Gadour (2006) mentioned that to resolve this problem, programmes for training school-level teachers of English were designed, but the local educational culture prevalent among teachers and learners had led to 
nothing ,because Libyan teachers of English had been accustomed to using old methodologies( following instructions) and to materials which were solely built on Libyan culture. In addition, the generation of students who graduated during the time when English was not being taught are still limited in their ability to take advantage of existing opportunities with western countries, such as work opportunities at foreign companies in Libya (pp. 180-182).

The IAU (2009) displayed that after the welcoming of English, the Committee of Higher Education (NOW; it become the Ministry of Higher Education after the fallen of the Gadhafi regime 2011) arranged a massive scholarship programme abroad to allow more than 80,000 teachers and students to get MAs and PhDs from different western countries, such as the UK and the USA, from 1999 to 2010. Scholarships had moreover been offered for graduate students and teachers before 1986 but there were very few scholarships from 1991 to 1999 (only 1,733). This reopening of scholarships (after 1999) created two generations of teachers (p.36). furthermore, the Libyan Ministry of Higher Education mentioned in its annual report that between 2011 to 2013 the scholarships strengthened to cover school teachers, high school graduates, employers form several sectors which opened wider opportunities of teaching and learning English.

\section{Brief From Literature}

1. Continuing Professional Development

Rodrigues (2004) showed that "CPD is any process or activity that provides added value to the capability of the professional through the increase in knowledge, skills and personal qualities necessary for the appropriate execution of professional and technical duties, often termed competence" (p. 11).

Bell et al (2001) stated that teachers can review, renew and extend their commitment as agents of change to the moral purposes of teaching; and through this they acquire and develop critically the knowledge, beliefs, skills and emotional intelligence important to excellent professional thinking, planning and practice with children, young people and colleagues through each phase of their teaching lives (p. 4).

Kanu (2005) also suggested that CPD serves longer term goals and seeks to facilitate the development of teachers' understanding of teaching as well as understanding themselves as teachers (p. 499). Rodrigues (2004) showed the aims of CPD from a second or foreign language development perspective can cover any of the following: the process of how second/foreign language development grows; learning how roles transform according to the kind of the learners being taught; reviewing theories and principles of foreign language teaching; determining learners' perceptions of classroom activities; developing an understanding of different styles and aspects of teaching; understanding the sorts of decision making that occur during foreign language lessons and building awareness of instructional objectives to support teaching (pp. 5-6).

Also, Guskey (2002) offered four models of professional development as vehicles for changing teaching practice, leading to developments in student achievement and outcomes, and changes in teachers' beliefs and attitudes (p. 382). In other words, the process of CPD is usually linked to teachers' careers and development. According to the importance of training and CPD, the LEFLSTs may find the idea of CPD valuable, and then they might find a possible model which accords with their existing culture situation.

Strategies of CPD.

Lo (2005), showed that "Professional Development should go beyond personal and individual reflections, for example, it can include exploration of new approaches and theories in language teaching" ( $p$. 140).

Elmabruk (2008) suggests that encouraging EFL Libyan teachers towards CPD will help them discover a suitable approach to CPD or training ideas. In other words, because of the existing lack of CPD or any managed training program in Libya, the LEFLSTs possibly may find the approaches of CPD valuable strategies which facilitate their on-going development of their EFL teaching (p. 128). The UK's Department for Education and Science (DFES) (2000) suggested that CPD strategies should suit the needs of policy makers, and funding and university managers and increase teachers' pedagogic and knowledge skills. Also, CPD strategies should increase and progress teachers' individual performances and develop their teaching beliefs and abilities. It therefore involves much more than just training courses.

However, while many things can be learned about teaching through self-observation and critical reflection, many cannot. These include subject matter knowledge, pedagogical expertise, and understanding of curricula (pp. 126-127).

Kennedy (2005) suggests that "CPD can be structured and organised in a number of different ways, and for a number of different reasons" (p. 236). She offered three main types of CPD models: transmissional, transitional and transformational. Every type has its own models for applying CPD. Most of these types and models are linked to the fundamental view of CPD applications. Guskey (2009) proposed that those in charge of planning and implementing professional development should learn how to critically assess the effectiveness of what they do. This means discussions about the specific aim of professional development, to determine what evidence best reflects the achievement of those aims, and what evidence can be collected in meaningful and 
scientifically defensible ways, should become the first point for all planning activities (p.498). Kennedy (2005) suggests that "CPD can be structured and organised in a number of different ways, and for a number of different reasons" (p. 236).

\section{Action Research}

Greenwood \& Levin (1998) pointed out that Action research is a form of research that generates "knowledge claims" for the express purpose of taking action to promote social change and social analysis. But social change we refer to is not just any kind of change. "Action research aims to increase the ability of the involved community or organization members to control their own destinies more effectively and keep improving their capacity to do so" ( p.7). Hittleman et al (2006) describes action research as teacher research, collaborative investigation and participatory action research (a systematic inquiry in which professional academic researchers conduct research with, rather than on or for, teachers, administrators, and even sometimes parents and students (p. 55). McNiff et al (1996) pointed out that the participants of action research are often "practitioners in the field being studied and include stakeholders in the professional community. The practitioners are no longer 'objects' to be studied, but assume the role of contributors" (p. 33). Guskey (2000) states that:

The idea of action research is that educational problems and issues are best identified and investigated where the action is: at the classroom and school level. By integrating research into these settings and engaging those who work at this level in research activities, findings can be applied immediately and problems solved more quickly. (p.65)

Baumfield (2008) pointed out that "Action research located within more traditional academic contexts tends to orient the process away from explicitness of the intentions of the activity towards concentrating on the process and the audience" (p.8)

Levin and Greenwood (2001) stated that "action research is more than the traditional interpretative research in the sense that the researcher is directly involved in the research setting and in the experience itself and has direct impact on the events being studied". These activities might be useful for the LEFLSTs, as it starts with clear steps that might encourage teachers to apply. Also, they mention that the value of action research lies in empirical and research evidence which can help educationalists to better understand and learn from their own practice through the investigation of different perspectives and rehearse and test responses to them. Thus, action research provides the "ideal approach" to reduce the problems inherent to preconceived conceptualisations of learning needs and strategies and the consequent confusion, friction and even conflict in learning settings (p.266).

Burbank and Kauchack (2003) argued that action research is a term which refers to a practical method of looking at one's own work to check it is satisfactory. It is open ended and does not begin with a fixed hypothesis. It begins with an idea that the teacher develops, takes action, evaluates and then reflects on (p.499). The process of action research is shown in the following figure.

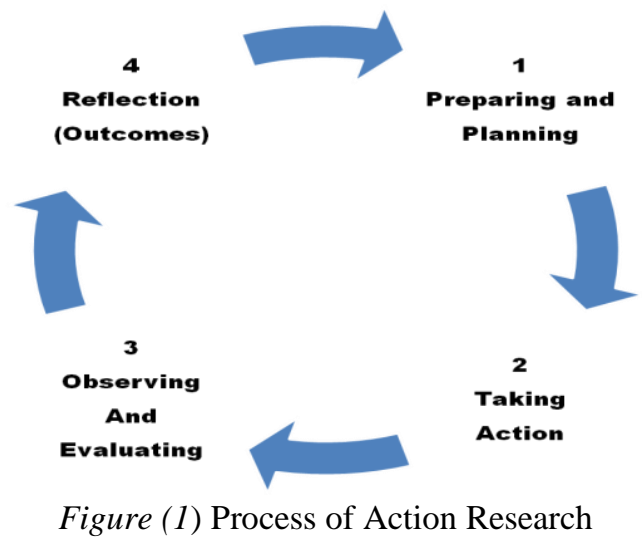

(Adapted from DFES, 2004 \& Ageila 2011)

\section{Action Research as a CPD Model}

Kennedy (2005) pointed out that action research as a model of CPD has been recognised as being successful in providing teachers with opportunities to ask critical and important questions of their practice (p.250). Clare et al (2000) claimed that the action research approach could improve teachers' knowledge improvement in several ways:

A- Teachers engage in critical reflection on specific features of their curriculum and pedagogy, they get to know their students well, interact with them, observe them and gather data. 
B- They engage critically with the research literature related to their research.

C- They collaborate with their peers and they modify curriculum and pedagogy in ways that allow their students and meet a wide range of their educational needs (pp.117-118).

The Research Questions (Reminder)

\section{The Methodology}

- To what extent are knowledge and cultural constrains faced by the LEFLSTs influence they ways, choices, and methodologies of teaching?

- To what extent are the possibilities of implementing Action Research as CPD among LEFLSTs?

The methodological steps and procedures which took place in the process of this research; a qualitative research method through observation and semi-structured interviews has been chosen as the main research tools for this research.

\subsection{The Observation Tool Focused On Observing:}

- Teachers lesson plan and ways of applying it within classes.

- Teaching methodologies implemented with each and every language skill.

- Teachers' knowledge of how learners learn?

- Teacher's techniques and abilities of teaching multi-level learners.

- Teachers' confidence of using the language.

- Teaching aids and literacy.

- Teachers' considerations of motivation and interaction.

- Teachers' knowledge of subject matter and knowledge of curriculum.

- Students' learning styles and responses.

- Students' abilities of accepting new methods and methodology

- Impacts of inspectors and headquarters on the teaching and learning process.

\subsection{The Semis -Structured Interviews Focused On}

- The teachers views on their faced difficulties

- Their views about how do they assist their teaching process.

- In depth questions about their knowledge of the importance of teachers training and CPD.

- Teachers' abilities of addressing their students' circumstances and their suggested solutions.

- Impacts of the culture on their choses of teaching and even learning; i.e. lifelong learning and continuing professional Development.

\section{Qualitative Research}

Since the process of qualitative research supports the researcher in gathering valuable data and findings, it will help to understand the situation of LEFLSTs. Bogdan and Biklen (1998) add that "qualitative research is conducted in the natural world, and uses multiple techniques that are interactive and holistic. It allows for the collection of data that is rich in description of people, the investigation of topics in context, and an understanding of behaviour from the participants' own frame of reference"(p.10). Holliday (2005) states that there is an assumption that qualitative research is "going to be 'open-ended', to look deeply into the participants' behaviour within the specific social settings" (p.5). While Lincoln (2000) stated that qualitative research involves an "interpretive and naturalistic approach. This means that qualitative researchers study things in their natural settings, attempting to make sense of, or to interpret, phenomena in terms of the meanings people bring to them" (pp.3-4).

Lincoln and Guba (1985) claim that "dependability" in qualitative research, which closely corresponds to the notion of "reliability", can be achieved by an "inquiry audit' as one measure which may enhance the dependability of qualitative research" (p.45). Also, McMillan and Schumacher (2006) reported that validity refers to the degree of congruence between the explanations of the phenomena and the realities of the world (p.90).

Denzin \& Lincoln (2000) showed that the issues of validity and reliability in qualitative research correspond to the criteria of truthfulness - credibility to internal validity, transferability to external validity, dependability to reliability, and conformability to objectivity (p.117). This study attempts to consider and present the "trustworthiness" of the research data collection tools, and therefore its findings, by respecting and applying the issues of validity and reliability in qualitative research. 


\subsection{Consideration Of Other Research Tools}

At first sight, it may seem more empirical to have used a quantitative approach, however with the situation in Libya of small numbers of English teachers unfamiliar with this kind of research and as I didn't have access to other schools, I felt I could overcome cultural challenges to research better by using a qualitative approach. I therefore concluded that if I handed out questionnaires among LEFLSTs who have strong cultural influences and poor research experience, everybody may be suspicious of it, and they may answer just for the sake of answering. In other words, I surveyed and considered all research tools before I decided what is culturally appropriate for conducting this research process.

\subsection{The Research Participants}

The participants are 12 Libyan participants teaching English at the high school of alkalidat. 10 female and 2 males; 5 teachers 3 females and 2 males have been teaching at the school for over 19 years .7 female teachers have been teaching between 6 to 10 years.

\subsection{Data Analysis}

Patton (2002) showed that content analysis is "any qualitative data reduction and sense-making effort that takes a volume of qualitative material and attempts to identify core consistencies and meanings" (p.453). Mayring (2000) showed that content analysis is "an approach of empirical, methodological controlled analysis of texts within their context of communication, following content analytic rules and step by step models, without rash quantification" (p.2). Hsieh and Shannon (2005) added that qualitative content analysis is "a research method for the subjective interpretation of the content of text data through the systematic classification process of coding and identifying themes or patterns" (p.1278). Schamber (2000) added that content analysis is an observational tool for identifying variables in text and an analytical tool for categorisation (p.739).

\subsection{Duration Of The Data Collection}

The overall duration was complete semester which is 14 weeks which consist of 168 English lessons for each year (each high school level). I observed 25 first year lessons, 19 second year lessons and 30 third year English lessons; as each lesson last 45 minutes. Also, as mentioned the interviewees were 12.

\section{Summary Findings}

Through observation and interviews analysis, revealed important findings and themes to discuss and link to theory. The analysis identified the difficulties LEFLSTS. These difficulties relate to findings such as the different background knowledge among LEFLSTs, their different views about teaching and learning and impact of their culture and beliefs on their practices. These linked findings on culture/beliefs, views, and the existing knowledge of the participants. Also, through the process of observation, it has been noticed that most teachers are using the grammar translation methods, drilling, and observing their students according to their memory. Similarly, most of them showed unsatisfactory about the non-existence of teacher training, time managements, and the inspectional system.

6.1. The main findings (THEIR FACED DIFICULTIES) could be summarised as follows:

(a) lack of knowledge and skill development within the school which caused very poor and frustrated teachers (b) top down influence from management or inspection within the school; this due to the ministry and policy makers (c) NO facilities and resources, such as the internet, books, PowerPoint, etc. (d) large number of students within each classroom (e) and academic atmosphere, motivation and collaboration among teachers.

6.2. Summary Findings: Overall Research Findings

- Libyan beliefs and culture have a strong impact as many teachers find it hard to apply different ideas, methods, and methodologies to their EFL classes.

- There is a strong impact of beliefs, the Libyan community control according to age, and the political setting in the way teachers make decisions and deal with managers.

- The age and gender of teachers and students influence academic collaboration amongst them, as teachers face difficulties of age and gender which influenced their relationship with each other.

- The poor facilities and resources within the University impact on the teaching and learning processes.

- The very large number of students impacts on the learning and teaching performance.

- The poor motivation and lack of collaboration among teachers has a negative impact on their teaching performance. 


\section{Researcher's Recommendations}

It would recommended that interested teachers arrange short classroom action research studies in areas such as students' learning styles, dealing with large groups of students, and methods of teaching used in pairs. Then they should discuss their outcomes with other teachers or other interested people. Also, it encouraged that interested teachers to interact with their interested students for more research, ideas, and feedback activities.

- It would recommend that the school support CPD activities among its teachers and create professional development plans and ideas.

- It would recommend encourage the school to promote more facilities, such as the internet, libraries and language labs.

- Finally, I would recommend taking a bottom-up rather than a top-down approach. This point could occur through giving more freedom to teachers' suggestions and start building the future plans from the existing situation instead of following the instructions from the top.

\section{Reference}

[1]. Agnaia, A. A. (1996). Assessment of management training needs and selection for training: The case of Libyan Companies. International Journal of Manpower. 17(3), 31-51.

[2]. Alexander. S .V (1991). Coming to terms: How researchers in learning and literacy talk about knowledge. Review of Educational Research 61(3) 311-329.

[3]. Appleton K. (2002). Science activities that work: perceptions of primary school teachers, Research in Science Education 32, 393410 .

[4]. Ball, D. L. \& Bass, H. (2000). Interweaving content and pedagogy in teaching and learning to teach: Knowing and using mathematics. In J. Boaler (Ed.) Multiple Perspectives on Mathematics of Teachin and Learning. (83- 104). Westport, Conn.: Ablex Publishing.

[5]. Ball, D. L., Thames, M. H., \& Phelps, G. (2008). Content knowledge for teaching: What makes it special? Journal of Teacher Education 59, 398-407.

[6]. Berg, B. L. (2004). Qualitative research methods for the social sciences. Boston: Allyn and Bacon.

[7]. Bogdan, R. C. \& Biklen, S. K. (1998). Qualitative research for education: An introduction to theory and methods. Boston: Allyn and Bacon.

[8]. Borg, M. (2001). Teachers' beliefs. ELT Journal 55(2), 186-187.

[9]. Borg, S. (2003). Teacher cognition in language teaching: A review of research on what language teachers think, know, believe, and do. Language Teaching 36(2), 81-109.

[10]. Brown, S. \& D. McIntyre (1993). Making sense of teaching. Buckingham: Open University Press.

[11]. Calderhead, J. (1996). Teachers: Beliefs and knowledge. In D. Berliner \& R. Calfee (Eds.) Handbook of research on educational psychology. New York, NY: Macmillan, 709-725.

[12]. Cobb, P. \& McClain, K. (2001). An approach for supporting teachers' learning in social context. In F.-L. Lin \& T. J. Cooney (Eds.) Making sense of mathematics teacher education (207-232). Dordrecht, The Netherlands: Kluwer.

[13]. Cohen, L., Manion, L. \& Morrison, K. (2000). Research methods in education. London: Routledge Falmer.

[14]. Coldron, J. \& Smith, R. (1999). Active location in teachers' construction of their professional identities. Journal of Curriculum Studies 31(6), 711-726.

[15]. Cole, A. L. \& Knowles J. G. (2000). Researching teaching: Exploring teacher development through reflexive inquiry. Boston: Allyn and Bacon.

[16]. Connelly, F. M. \& Clandinin, D. J. (1985). Personal practical knowledge and the modes of knowing, In E. Eisner (Ed.) Learning and teaching the ways of knowing (174-198). Chicago: University of Chicago Press.

[17]. Connelly, F. M., Clendenin, D. J. \& He, M. F. (1997). Teachers' personal practical knowledge on the professional knowledge landscape. Teaching \& Teacher Education 13(7), 665-674.

[18]. Creswell, J.W. (2003). Research Design: Qualitative, Quantitative, and Mixed Methods Approaches. Thousand Oaks, CA: Sage

[19]. Curran, E., \& Murray, M. (2008). Transformative learning in teacher education: Building competencies and changing dispositions. Journal of Scholarship of Teaching and Learning, 8, 103-118.

[20]. Deborah L. B., Mark, H.T. \& Geoffrey, P. (2008). Content knowledge for teaching: What makes it special? Journal of Teacher Education 59, 389-407.

[21]. Desimone, L. M. (2009). Improving impact studies of teachers' professional development: toward better conceptualisations and measures. Educational Researcher 38, 181-199.

[22]. Elbaz, F. (1991). Research on teacher's knowledge: The evolution of a discourse. Journal of Curriculum Studies 23(1), 1-19.

[23]. Elbaz, F. (1983). Teacher Thinking: A study of Practical Knowledge. London: Croom Helm.

[24]. El-Hawat, A. (2006). Globalization, modernization and education in Libya. In R. Zia (Ed.) Globalization, Modernization and Education in Muslim Countries. (207-221) New York, NY: Nova Science Publishers.

[25]. El-Hawat, A. (2003). Libyan education. In D. Teferra \& P. G. Altbach (Eds.) African Higher Education: An International Reference Hand Book. (391-402) Bloomington: Indiana University Press.

[26]. Fennema, E. \& Franke, M. L. (1992). Teachers' knowledge and its impact. In D.A. Grouws (Ed.) Handbook of research on mathematics teaching and learning. New York: Macmillan, 147-164.

[27]. Freeman, D. \& Graves, K. (2004.) Examining language teachers' teaching knowledge. In M. Hawkins \& S. Irujo (Eds). Collaborative conversations among language teacher educators. Alexandria: TESOL, 87-104.

[28]. Freeman, D. \& Johnson, K. E. (1998). Reconceptualizing the knowledge-base of language teacher education. TESOL Quarterly 32(3), 397-417.

[29]. Freeman, D. \& Richards, J. C. (1996). Teacher learning in language teaching. Cambridge Eng.; New York: Cambridge University Press.

[30]. Gadour, A. (2006). Libyan children's views on the Importance of school factors which contributed to their emotional and behavioural difficulties. School Psychology International 27(2), 171-191.

[31]. Giroux, H. A. \& Simon, R. I. (1988). Schooling, popular culture, and a pedagogy of possibility. Journal of Education 170(1), 9-26. 
[32]. Goettsch, K. \& Johnston, B. (2000). In search of the knowledge base of language teaching: Explanations by experienced teachers. Canadian Modern Language 299 Review 56, 437-468.

[33]. Groth, R. E. (2007). Toward a conceptualisation of statistical knowledge for teaching. Journal for Research in Mathematics Education 38, 427-437.

[34]. Grossman, P. (1990). The making of a teacher: Teacher knowledge \& teacher education. New York: Teachers College Press.

[35]. Gubrium, J. F. \& Holstein, J. A. (2000). Analyzing interpretive practice. In N. K. Denzin and Y.S. Lincoln (Eds.) Handbook of qualitative research ( $2^{\text {nd }}$ ed.). (487-508). Thousand Oaks, CA: Sage.

[36]. Gunstone, R. (1999). Content knowledge, reflection, and their intertwining: A response to the paper set. Science Education 83(3), 393-396.

[37]. Guskey, T. R. (2000). Evaluating professional development. Thousand Oaks, CA: Corwin Press. Guskey, T. R. (2002). Professional development and teacher change. Teachers and teaching Theory and practice 8(3/4), 381-391.

[38]. Guskey, T. R. (2003) What makes professional development effective? Retrieved from http://0proquest.umi.com.opac.library.usyd.edu.au:80/pqdweb?did=340168051\&sid=2\&Fmt= $3 \&$ clientld $=16231 \&$ RQT $=308 \&$ VName=PQD on July 17, 2013.

[39]. Guskey, T. R. (2009). What works in professional development. American instate for research 10(5), 494-499.

[40]. Hazel, N. (1995). Elicitation techniques with young people. Social Research Update 12. Retrieved from http://www.soc.surrey.ac.uk/sru/SRU22.html on June 30, 2013.

[41]. Hill, M. (1997). Research review: Participatory Research with Children. Child and Family Social Work 2, $171-183$.

[42]. Hoban, G. (2002). Teacher learning for educational change: A systems thinking approach. Buckingham: Open University Press.

[43]. Hoban, G.F. (2003) Teacher learning for educational change. Buckingham: Open University Press.Development 25(4), 493-513.

[44]. Hu, G. (2005). Professional development of secondary EFL teachers: Lessons from China. Teachers College Record 107(4), 654705.

[45]. International Association of Universities (IAU) (2009). Structure of educational system: Admissions to higher education recognition of Foreign Credentials. Retrieved from http://www.iau-aiu.net/ on 15 August 2013.

[46]. Kennedy, A. (2005). Models of continuing professional development (CPD): A framework for analysis. Journal of In-Service Education 21(2), 233-252.

[47]. Kennedy, C. (1987). Innovating for a change: Teacher development and innovation. ELT Journal 41(3), 163-169.

[48]. Kennedy, C. \& Kennedy, J. (1996). Teacher attitudes and change implementation. System 24(3), $104-111$.

[49]. Kennedy, J. (1999). Using mazes in teacher education. ELT Journal 53(2), 107-114.

[50]. Kennedy, J. \& Kennedy, C. (1998). Levels, linkages, and networks in cross-cultural innovation. System 26, $455-469$.

[51]. Khalifa, S. M. G. (2002). The use of computers in the teaching of mathematics in Libyan primary. Retrieved from http://hdl.handle.net/10068/508910 on Sep 2, 2013.

[52]. Lave, J. \& Wenger, E. (1991). Situated Learning: Legitimate Peripheral Participation. Cambridge: Cambridge University Press.

[53]. Meijer, P. C., Verloop, N. \& Beijaard, D. (1999). Exploring language teachers' practical knowledge about teaching reading comprehension. Teaching and Teacher Education 15(1), 59-84.

[54]. Mishra, P. \& Koehler, M. J. (2006). Technological pedagogical content knowledge: A new framework for teacher knowledge. Teachers College Record, 108(6), 1017-1054.

[55]. Ofsted (2000.) Secondary subject Inspection 1999/2000: University of Hull (Mathematics) London: Ofsted

[56]. Putnam, R. \& Borko, H. (1997). Teacher learning: implications of new views of cognition. In B. J. Biddle, T.L. Good, \& I.F. Goodson (Eds.) The International Handbook of Teachers and Teaching (1223-1296). Dordrecht, The Netherlands: Kluwer.

[57]. Rajab, A. (2007). Student attitudes in the context of the curriculum in Libyan education in middle and high schools. Unpublished PhD Thesis, University of Glasgow.

[58]. Randall, M. \& Thornton, B. (2001). Advising and supporting teachers. Cambridge: Cambridge University Press.

[59]. Richards, J. C. (1991). Reflective teaching in TESOL teacher education (FL022034). Issues in Language Education. Anthology Series 30. (ERIC Document Reproduction Service No. ED370357).

[60]. Richards, J. \& Lockhart, C. (1996). Reflective teaching in second language classrooms. New York, NY: Cambridge University Press.

[61]. Richardson, V. (1996). The role of attitudes and beliefs in learning to teach. In J. Sikula (Ed.) Handbook of research on teacher education. New York: Simon \& Schuster Macmillan, 102-119.

[62]. Roberts, J. (1998). Language Teacher Education. London: Arnold, a member of the Hodder Headline Group.

[63]. Sawani, F. (2009). Factors affecting English teaching and its materials preparation in Libya. Unpublished PhD Thesis, University of Essex.

[64]. Segall, A. (2004). Revisiting pedagogical content knowledge: The pedagogy of content/the content of pedagogy. Teaching and Teacher Education 20(5), 489-503.

[65]. Shank, G. (2002). Qualitative research. A Personal Skills Approach. Englewood Cliffs, NJ: Prentice-Hall.

[66]. Simon, R. I. (1992). Teaching against the grain: Texts for pedagogy of possibility. New York: Bergin \& Garvey.

[67]. Solis, A. (2009). Pedagogical content knowledge: What matters most in the professional learning of content teachers in classrooms with diverse student populations. IDRA. TAXAS

[68]. Stacey, K., Helme, S., Steinle, V., Baturo, A., Irwin, K. \& Bana, J. (2001). Pre-service teachers' knowledge of difficulties in decimal numeration. Journal of Mathematics Teacher Education 4, 205-225.

[69]. Strauss, A. \& Corbin, J. (1990). Basics of qualitative research: Grounded theory procedures and techniques. Newbury Park, CA: Sage.

[70]. UNESCO, International Association of Universities and Association of African Universities (2002) Guide to higher education in Africa. Hampshire: Palgrave Publishing. Retrieved from World Education News \& Reviews at http://wenr@wes.org.

[71]. Valencia, J. A. A. (2009). An exploration of Colombian EFL teachers' knowledge base through teachers' reflection. Linguagem \& Ensino, Pelotas 12(1), 73-108.

[72]. Vandewalle, D. (2009). A History of Modern Libya. Cambridge, UK: Cambridge University Press.

[73]. Verloop, N., Van Driel, J. \& Meijer, P. (2001). Teacher knowledge and the knowledge base of teaching, International Journal of Educational Research, 35(5), 441-461.

[74]. Wilson, K. (1999). Note-taking in the academic writing process of non-native speaker students: Is it important as a process or a product? Journal of College Reading and Learning 29(2), 166-179 